\title{
GAC-MAC:
}

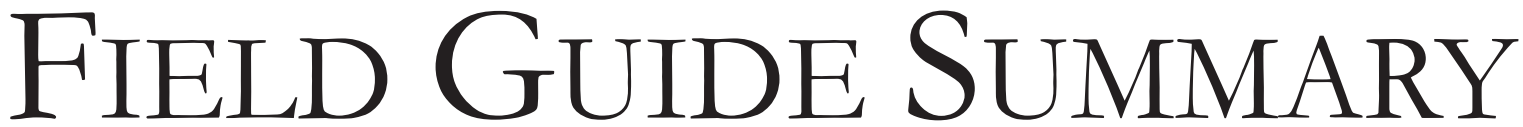

\section{Vancouver 2018: RFG 2018 / CIM-GAC- MAC Joint Annual Meeting Field Trips}

\author{
Dan Gibson \\ Department of Earth Sciences \\ Simon Fraser University, Burnaby, British Columbia \\ V5A 1S6, Canada \\ E-mail: hdgibson@sfu.ca
}

\section{RFG 2018 / GAC-MAC FIELD GUIDE SUMMARY}

The GAC-MAC Annual Meeting this year will be associated with the inaugural Resources for Future Generations (RFG) 2018 Conference that will be held in Vancouver, British Columbia. The conference theme is focused on exploring resource and sustainability issues, such that we can develop and utilize these resources in better, sustainable and cleaner ways that minimize impact. Vancouver, a coastal city surrounded by ocean, mountains, glaciers and forests, and whose essence is deeply entwined with natural resources, is a perfect setting for the RFG 2018 conference.

The RFG 2018 meeting will offer a wide variety of preand post-conference field trips that are aligned with the main themes of RFG 2018, including renewable energy and resources, hydrology, natural hazards, urban geology and geoheritage, metallogeny, geochemistry, structure, petrology and tectonics. In total, there are 15 field trips to choose from that range in length from local one-day field trips, to multi-day field trips in the southern interior of British Columbia, the foothills of Alberta and Nevada.

\section{Pre-Conference Field Trips}

Pre-conference field trips include a one-day excursion titled "Urban Geology and Geoheritage of Metro Vancouver, British Columbia." Participants will examine Metro Vancouver's bedrock and surficial deposits that span the last 200 million years of Earth history, as well as consider the breadth of societal contributions afforded by Urban Geology. Emphasis will be on the glacial history and geology of the region. Geotechnical challenges of the region will be examined including water resources, flooding and mass wasting. Challenges in recent tunnel construction in thick glacial and glacial-marine sediments for expansion of the Skytrain Light Rail Transit system will also be explored. In addition, the growing interest in geoheritage and the educational values of geological sites will be addressed along with their potential for fostering a sense of place for an increasingly diverse urban population.

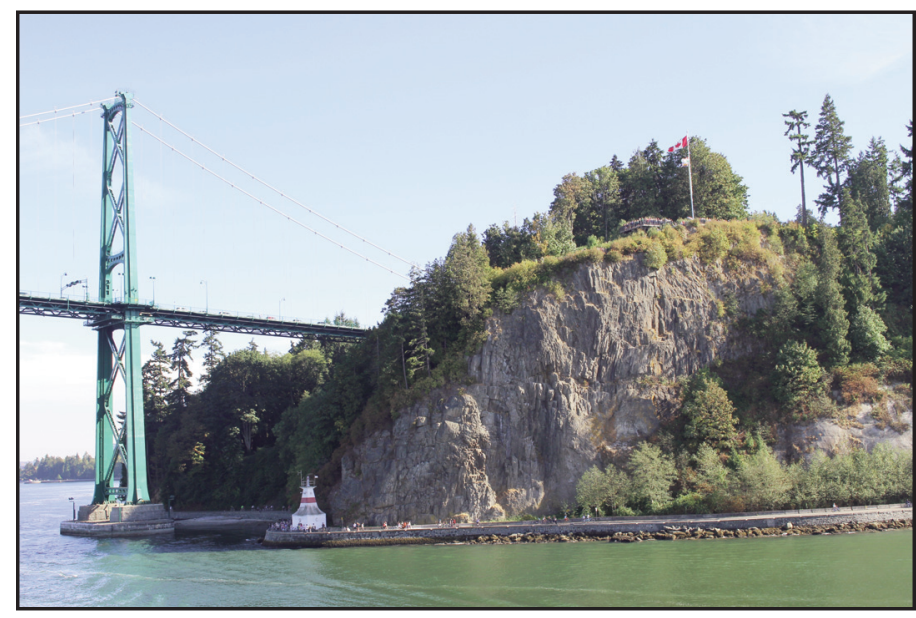

Columnar andesite, Stanley Park, Vancouver, British Columbia (Photo: Lionel Jackson).

Further afield, "The Cretaceous-Cenozoic Coast-Cascade Orogen: The Chilliwack Valley-Harrison Lake Connection" is a two-day field trip in a region that occupies an important position in a midCretaceous to Cenozoic (100-45 Ma) orogen whose southern extent includes the Coast and Cascade Mountains of southwestern British Columbia (BC). Here, there is excellent preservation of allochthonous terranes sandwiched between terranes to the east accreted in the Jurassic, and Wrangellia terrane to the west underlying most of Vancouver Island. The region is characterized by mid-Cretaceous to early Cenozoic granitic intrusions, metamorphic rocks, folds, thrust and reverse faults, all overprinted by late Eocene through Neogene volcanic rocks and plutons of the Cascade Magmatic Arc.

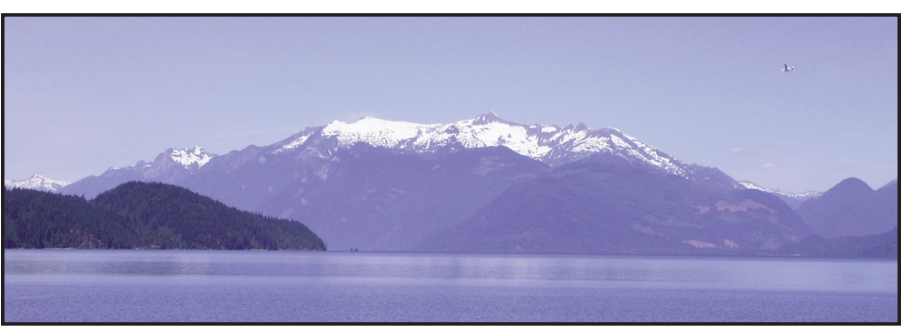

View of snowcapped peaks of mid-Cretaceous Breakenridge orthogneiss (up to 10 Kbar) adjacent to the little deformed and metamorphosed rocks of the Harrison Lake Formation (tree covered rocks in foreground to the left), southwestern British Columbia (Photo: Dan Gibson). 
Across the Salish Sea, a two-day field trip titled "Karst Hydrology of Central Vancouver Island" will examine two forested karst areas including: the Horne Lake Caves Provincial Park and Quadra Island. The focus for the field trip will examine how these karst landscapes influence the hydrology of the region. At Horne Lake Caves participants will explore the 'karst trail' and have a guided trip into the subsurface. Karst features and geology outside of the park will also be examined. At Quadra Island they will visit a series of karst springs as well as the associated recharge area.

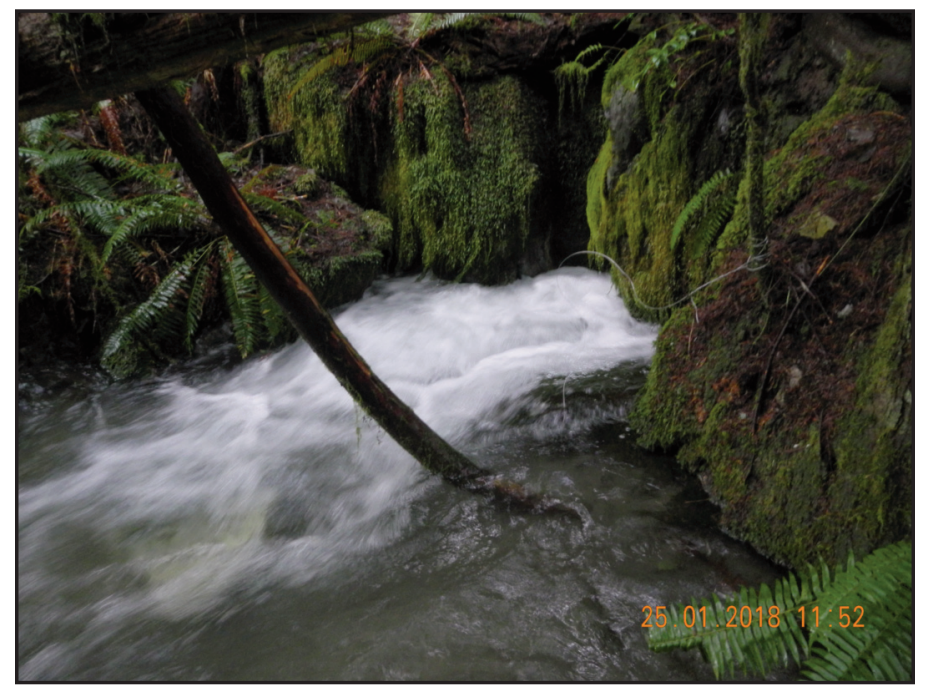

Karst spring, Quadra Island, British Columbia (Photo: Tim Stokes).

To the east within the southern interior of British Columbia, a six-day field trip titled "Southern BC Porphyry Field Trip," put on by the Mineral Deposits Research Unit (MDRU) of the University of British Columbia, focuses on the diverse porphyry $\mathrm{Cu}-\mathrm{Au}$ systems in the prolific Late Triassic Quesnel Terrane (Quesnellia). Participants will be exposed to various types of porphyry deposits, mineralization and alteration styles, mining methods, and background lectures near Kamloops and in the Copper Mountain district. Emphasis is placed on alkalic porphyry systems, characteristic of regional porphyry metallogeny.

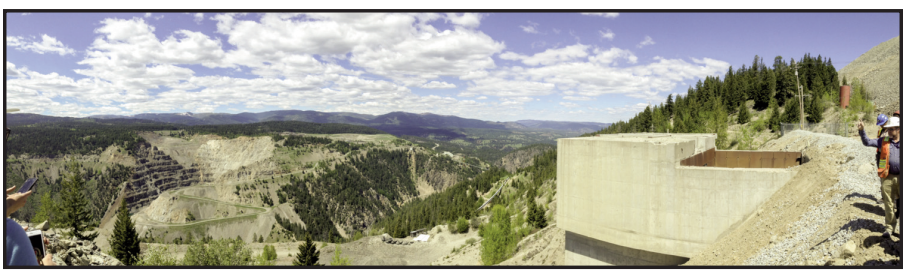

Copper Mountain mine, southern interior of British Columbia (Photo: Robert Lee).

\section{Post-Conference Field Trips}

The one-day post-conference field trips include a bus trip titled "Geology and Natural Hazards of the Sea-to-Sky Corridor" that takes you from Vancouver to Squamish. Topics addressed during field trip stops include the geology of the southern Coast Mountains, the origin of Howe Sound, Pleistocene glaciation of British Columbia, and geologic hazards on the south coast.
An underground tour of the Britannia Mine, once the largest mine in British Columbia, is included in the trip.

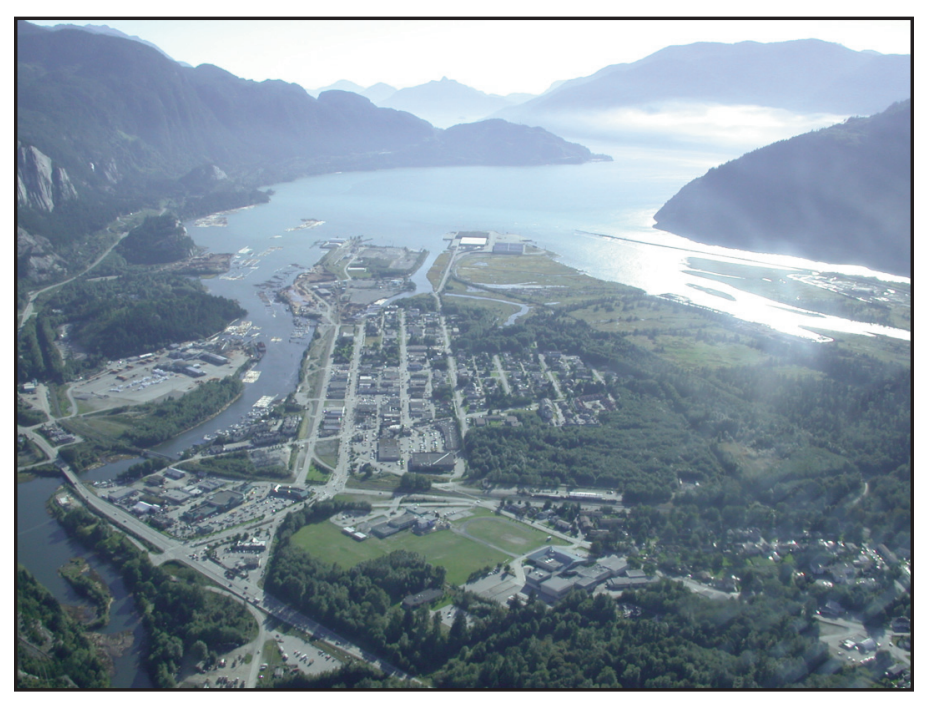

Howe Sound, a network of fjords northwest of Vancouver, British Columbia (Photo: John Clague).

Another local one-day field trip titled "Resourcing Urban Water - the Seymour-Capilano Water System and Twin Tunnels Project" will take in aspects of the geology of the mountainous north side of Vancouver harbour and will include visits to both the Capilano and Seymour watersheds to understand the Seymour-Capilano Twin Tunnels Projects and tour some of the associated facilities. The field trip will examine a major, modern urban water handling and treatment scheme that supplies domestic drinking water to 2.4 million local residents, at a rate of 1.8 billion litres per day.

A third one-day field trip titled "Seabreeze Farm Renewable Natural Gas Plant Tour" will examine a multi-generational family owned dairy operation in Delta, BC that produces Renewable Natural Gas (RNG) from the farm's dairy manure for injection into the FortisBC gas grid.

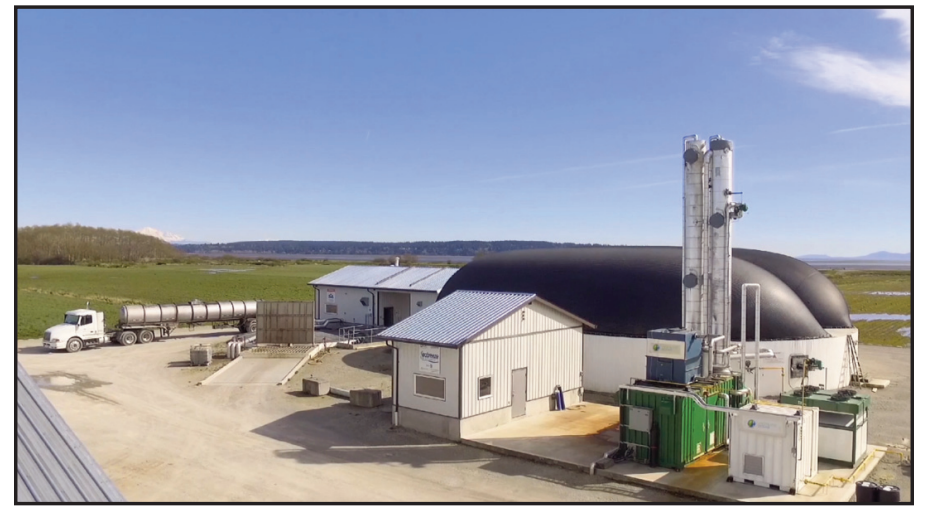

Seabreeze Farm Renewable Natural Gas plant, Delta, British Columbia (Photo: Greenlane Biogas).

A fourth one-day field trip titled "Geochemistry Lab 101" is offered in Metro Vancouver. The field trip will feature a morning technical seminar and an afternoon laboratory tour at one 
of two sponsoring Vancouver mineral laboratories (Bureau Veritas or SGS Canada Inc.). The trip is envisioned as a theoretical and practical learning experience for participants new to the industry or unfamiliar with geochemical analytical science.

The multi-day post-conference field trips range from 2.5 to 4 days in length. These include a 2.5-day field trip titled "Highland Valley Porphyry Copper Deposits: District-Scale Footprints" located near Merrit, British Columbia. This field trip will examine the magmatic evolution, mapped alteration, outcrop hyperspectral response, and the lithogeochemical and Carbon isotope footprints around the Highland Valley Porphyry $\mathrm{Cu}$ (HVC) deposits that are hosted in the Late Triassic Guichon Creek batholith within Quesnel terrane.

South of the $49^{\text {th }}$ parallel, another 2.5-day field trip titled "Navigating a porphyry Cu bydrothermal system: Alteration and geochemical dispersion mapping" will examine the geology, hydrothermal alteration mineralogy, and geochemical dispersion around Yerington, Nevada, USA. Yerington is a classic locality where porphyry $\mathrm{Cu}$ deposits, high level $\mathrm{Fe}$-oxide deposits, and a volcanic and plutonic complex have been tilted $80^{\circ}$ on to their side so that a complete $3-\mathrm{D}$ picture of a zoned magmatichydrothermal system is exposed.

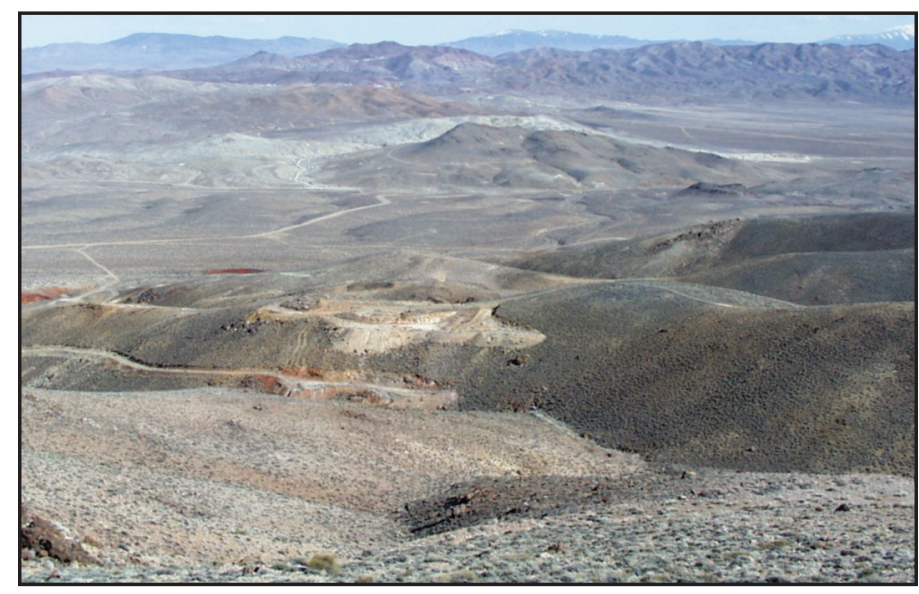

Yerington, Nevada - View from lithocap to porphyry across 3 fault blocks (Photo: Richard Tosdal).

There will be 3 three-day post-conference field trips. One of which titled "Geochemical Field Techniques" will explore glacial landforms on macro- and micro-scales and the sampling of soils, tills, sediments and vegetation. Topics covered include Quaternary geology, biogeochemistry, exploration geochemistry and analytical chemistry. Sampling techniques designed for defining baseline and anomalous trends employed in environmental and exploration geochemistry on property, reconnaissance and global scales will be explored. Visits to two mineral deposits include a reclaimed massive sulphide deposit on the $\mathrm{BC}$ mainland and a porphyry $\mathrm{Cu}-\mathrm{Au}$ prospect on Vancouver Island. In situ analysis of samples using field portable instruments (e.g. pXRF) combined with subsequent lab analyses of collected samples will give the participants a full appreciation of discovering geochemical anomalies and tracing these to mineralization.
Another three-day field trip within southeastern BC titled "Upper Fir Carbonatite-Hosted Nb-Ta Deposit" visits the Upper Fir carbonatite complex (330 Ma) hosting one of the largest and best studied $\mathrm{Nb}-\mathrm{Ta}$ deposits within the Omineca belt of east-central British Columbia (Blue River area). Although the late Paleozoic carbonatites formed in an active tectonic setting, they are mineralogically and isotopically indistinguishable from worldwide carbonatites generated by deep-mantle plumes in intracratonic settings. Participants will examine late Paleozoic pillowed basalts along the way to Blue River and a range of metamorphic rocks and structures at Upper Fir. In a wider context, the trip will evaluate back-arc extension from eastward subduction beneath ancestral North America and its possible connections to mantle plume development that may have triggered formation of the Slide Mountain ocean.

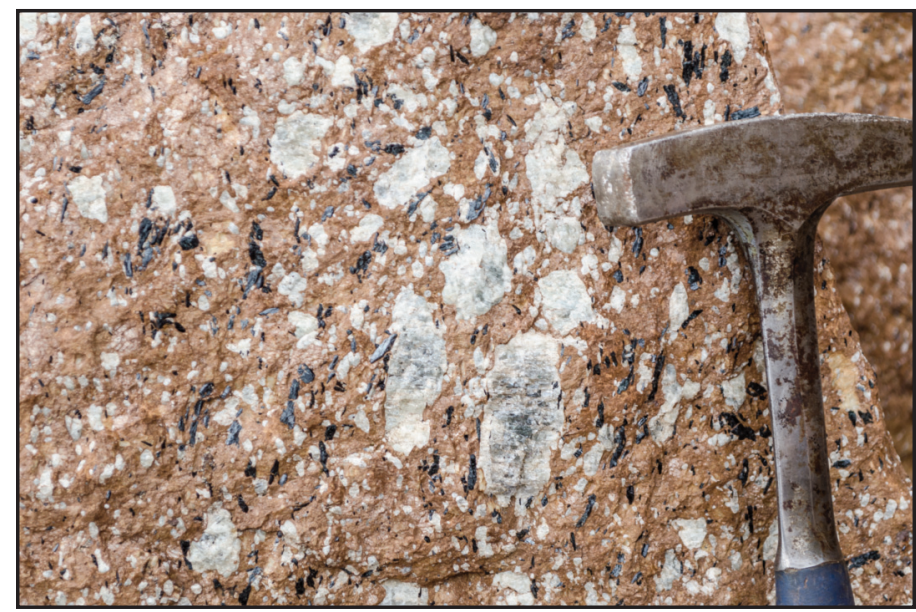

Upper Fir carbonatite - apatite and ferrikatophorite in a Fe-dolomite matrix; southeastern British Columbia (Photo: Alexei Ruklov).

Farther east, another three-day field trip will be offered, titled "The southern Canadian Rocky Mountains - Front Ranges and Foothills." This field trip, within a picturesque part of southern Alberta, focuses on the geological evolution of the Foreland thrust and fold belt between the Foothills and Front Ranges from Banff to the US border.

There will be 2 four-day post-conference field trips offered. The first is titled "The Tulameen Alaskan-type ultramafic-mafic intrusion: architecture, emplacement mechanisms and Cr-PGE vs CuPGE 'Reef-style' mineralization in a convergent margin setting." This field trip near Tulameen, BC, will examine the lithological zoning and temporal evolution of the Tulameen Alaskan-type intrusive complex and contrasting styles of chromitite-PGE mineralization in the dunite core versus newly encountered $\mathrm{Cu}-\mathrm{PGE}$ sulphide mineralization in the more differentiated ultramafic rocks. Highlights include examination of 'magmatic avalanche' deposits exposed in the Tulameen River bed, and a $700 \mathrm{~m}$ zone of $\mathrm{Cu}-\mathrm{PGE}$ mineralization similar to $\mathrm{Cu}-\mathrm{PGE}$ 'reef' occurrences documented from layered intrusions in extensional tectonic settings. This trip complements the Special Session: "Advances in the study of platinum group elements and ultramafic rocks." 


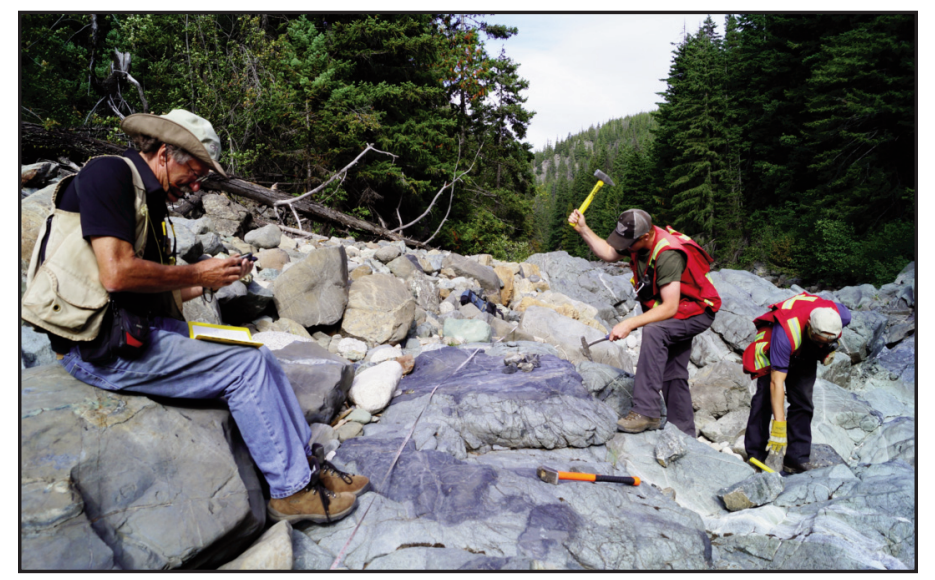

Dunite-clinopyroxenite outcrop in the Tulameen River bed, near Tulameen, British Columbia (Photo: Nichole Moerhuis).

The other four-day field trip titled "Torrents, Terrains and Tuyas-Waterfall and Volcanoes of South Central British Columbia" will highlight BC's magnificent mountain scenery, provincial parks, volcanoes and especially its water falls. The trip is suitable for the specialist and non-specialist alike. The group will investigate a zone of transition between the Cariboo and Monashee mountain ranges where deep crustal faults have provided pathways for mafic magmas producing the Wells Gray-Clearwater volcanic field. Here, the interaction between volcanism and multiple glaciations over a three-million-year period have created rugged terrain and unique subglacial landforms called 'Tuyas.' River valleys cut the landscape. The vertical lava walls create spectacular water falls, including Canada's fourth highest - Helmcken Falls. In addition to the stunning vistas, there will be opportunity of hands-on examination of complex stratigraphy related to volcano-glacier interaction.

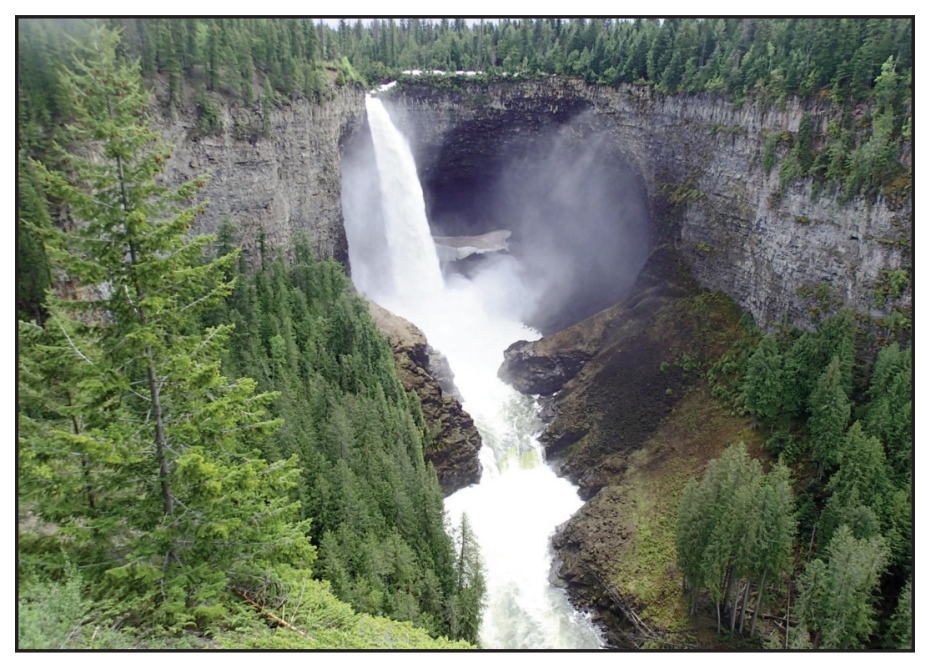

Helmcken Falls cutting through Wells Gray-Clearwater volcanic field; Wells Gray Provincial Park in south-central British Columbia (Photo: Catherine Hickson).

We hope this wide assortment of field trips will appeal to the broad geoscientific community and that you will visit Vancouver for RFG 2018. See you in June! Further information can be found at: www.rfg2018.org.

\section{GEOSCIENCE CANADA} THE JOURNAL YOU WANT TO READ....

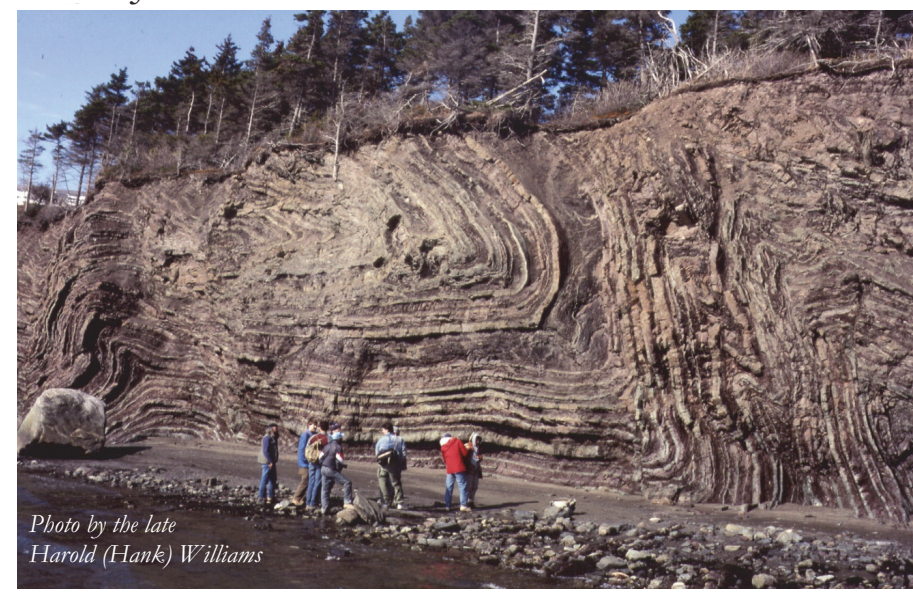

The Appalachians weren't built in a day.

The same applies to a world-class journal.

Geoscience Canada is a quarterly journal published by the Geological Association of Canada (GAC). We are a not-for-profit publication funded by subscriptions, grants and the generous support of researchers and readers. The content of the journal is diverse, ranging from technical papers to review articles, commentaries, columns and book reviews. We offer a smooth and personalized approach to the review and processing of papers, and accepted contributions will generally appear as 'in press' within a few months of their initial submission, and in final form within six to nine months. We have a particular interest in overview articles that have long-term educational value.

Annual subscriptions to Geoscience Canada cost much less than a daily cup of coffee from your favourite chain. GAC members can subscribe for a mere $\$ 50$ and non-members for only $\$ 75$ (only $\$ 15$ for students). Even if your institution already carries a subscription on your behalf, a convenient personal subscription helps to support non-profit Earth Science publishing in Canada, which benefits all. Visit our website and also GAC for more information.

www.geosciencecanada.ca

www.gac.ca

http://www.geosciencecanada.ca 